\title{
Clinicopathological profile and management of 161 cases of actinic cheilitis*
}

\author{
Maria Luiza Diniz de Sousa Lopes ${ }^{1}$ \\ Kenio Costa Lima ${ }^{1}$ \\ Éricka Janine Dantas da Silveira ${ }^{1}$
}

\author{
Francisco Leonardo da Silva Júnior ${ }^{1}$ \\ Patrícia Teixeira de Oliveira ${ }^{1,2}$
}

DOI: http:/ / dx.doi.org/10.1590/abd1806-4841.20153848

\begin{abstract}
BACKGROUnD: A ctinic cheilitis (AC) is a potentially malignant disorder of the lip caused by chronic exposure to ultraviolet radiation from the sun.

ОвлестіvEs: To evaluate the clinical, demographic, morphological and therapeutic management in AC cases data associating to the histopathological grading.

Methods: Demographic, clinical and management data of 161 patients with AC were analyzed. In biopsied cases, two calibrated examiners performed histopathological grading by binary system.

REsults: There was a prevalence of males (79.5\%), aged 40 years or older $(77.5 \%)$, light-skinned (85.7\%), experiencing occupational exposure to sunlight $(80.3 \%)$, with AC presenting clinically as white lesions (33.6\%). Conservative treatment was adopted in 78 cases and biopsy in 83 cases $(60.2 \%$ graded as low-risk $A C)$. There were no significant associations between histopathological grading and gender $(p=0.509)$, age $(p=0.416)$, ethnicity $(p=0.388)$, occupational exposure to sunlight $(\mathrm{p}=1.000)$ or clinical presentation $(\mathrm{p}=0.803)$.

Conclusion: This study reinforces the hypothesis that demographic and clinical characteristics of AC are not related to histopathological grading. Advice on protection from sun exposure should be encouraged to avoid progression of $\mathrm{AC}$ and invasive therapies.
\end{abstract}

Keywords: Cheilitis; Lip; Therapeutical approaches; Ultraviolet rays

\section{INTRODUCTION}

Actinic cheilitis (AC) is a common, potentially malignant lesion that affects the lip. ${ }^{1}$ Its main etiological factor is chronic exposure of the lips to ultraviolet (UV) radiation from the sun, especially type $B$ (UVB), due to its greater penetration potential, compared with type A (UVA). ${ }^{2}$ It is estimated that $95 \%$ of squamous cell carcinomas (SCC) of the lip originate from ACs. ${ }^{3}$

$\mathrm{AC}$ is more common in white men, especially those who experience occupational sun exposure, such as fishermen and agricultural workers. ${ }^{1,4}$ The most common clinical presentation is pale, scaly lips, presenting with a dry area of varied thickness and associated erythema; while at advanced stages, leukoplakia and/or erithroplakia areas appear, potentially along with chronic ulcerations and erosions..$^{5}$

The histopathological spectrum of AC ranges from hyperkeratosis (with or without epithelial

Received on 17.07.2014.

Approved by the Advisory Board and accepted for publication on 09.09.2014

Work performed at the Departamento de odontologia da Universidade Federal do Rio Grande do Norte (UFRN) - Natal (RN), Brazil.

Financial Support: None.

Conflicts of interest: None.

Universidade Federal do Rio Grande do Norte (UFRN) - Natal (RN), Brazil.

Universidade Potiguar (UnP) - Natal (RN), Brazil.

(C2015 by Anais Brasileiros de Dermatologia 
dysplasia) to carcinoma in situ in the presence of basophilic changes in the lamina propria (alteration of collagen and elastic fibers induced by UV), plus inflammation and vasodilation. ${ }^{6,7}$ Invasive SCC can also be found on histolopathogical examination, with clinical suspicion of AC. ${ }^{6}$

Severalchanges related to ACmay beirreversible, but even then patients should be instructed to use lip sunscreen and change their sun exposure habits to prevent further damage. ${ }^{8}$ It is important to monitor periodically AC patients and perform incisional biopsies in lesions with more severe clinical aspects in order to prevent their malignant transformation. In cases involving severe microscopic characteristics, with clear malignant transformation, therapeutic methods include surgical excision (vermilionectomy), cryosurgery and laser surgery. ${ }^{9}$

Drawing on knowledge of the epidemiological profile and clinical and histopathological findings, clinicians can make an accurate, early diagnosis and arrange effective treatment. Thus, this study aimed to verify the demographical and clinicopathologic profile in a series of AC cases treated at a univeristy oral diagnosis department, and identify the management instituted for these patients.

\section{METHODS}

This was an observational, longitudinal and retrospective study, based on an analysis of the medical records and follow-ups of all patients diagnosed with AC who were treated at the Oral Diagnosis Department of the Federal University of Rio Grande do Norte, between January 2000 and October 2013. It included all cases whose files contained the necessary information to conduct the research, constituting 166 cases. Five cases were excluded because the histopathological diagnosis was SCC of the lip, thus leaving a final sample of 161 cases. The Research Ethics Committee of the Federal University of Rio Grande do Norte (CEP/UFRN 317/2012) approved the study.

Initially, we conducted a survey of all patients registered at the aforementioned department with a clinical diagnosis of $\mathrm{AC}$, followed by analysis of medical records in order to obtain information such as: gender, age, ethnicity, job (occupational exposure to sunlight), habits (smoking and alcohol consumption) and clinical features. Management data was also analyzed and classified, as they needed conservative treatment (sun protection and use of topical corticosteroid) or biopsies. All patients were invited to return to the department for follow-up, as well as to verify the outcome, recurrence or re-epithelialization of lesions. However, due to patients' unavailability or difficulties to contact them, few patients returned and therefore the study excluded these data.
Cases submitted for biopsy were retrieved from the Oral Pathology archives in the Department of Dentistry, Federal University of Rio Grande do Norte. Subsequently, 5 - $\mu$ m-thick sections were cut, deparaffinized, and stained by hematoxylin/eosin for morphological analysis and histopathological grading by two experienced pathologists. The classification criteria recommended by Kujan et al. ${ }^{10}$ were used to grade ACs at low-risk and high-risk of malignant transformation.

Data were imported to SPSS version 20.0 software (SPSS, Inc., Chicago, IL, USA). Descriptive analyses of all variable data were carried out, in addition to Fisher's exact and Pearson's chi-squared tests, to verify the possible association between histopathological grading (low-risk or high-risk AC) and gender, age ( $\geq 40$ years or $<40$ years), ethnicity, occupational exposure to sunlight (yes or no), smoking, alcohol consumption and clinical appearance of AC (white lesions or red lesions/white and red lesions). A significance level of $5 \%$ was adopted for all tests.

\section{RESULTS}

Table 1 outlines the clinicpathological profile of the sample of 161 AC patients, who were primarily male $(79.5 \%)$, light-skinned $(85.7 \%)$ and aged over 40 $(77.5 \%)$. The mean \pm standard deviation (SD) age at the time of diagnosis was $51.98 \pm 16.58$ years. With regard to habits, most patients were nondrinkers (85.3\%) and nonsmokers (70.6\%). Approximately 80\% of the sample reported daily sun exposure due to their occupations, which included farming, construction work and firefighting.

Almost all cases occured in the lower lip $(97.5 \%)$ and the most frequent clinical features were white plaques (33.6\%), red and white plaques $(26.6 \%)$ and red plaques (25.9\%). Pigmented areas (5.6\%) and ulcerations $(5.6 \%)$ were also reported. Pain was present in $28.4 \%$ of cases, while in $24.7 \%$ there were reports of stinging/burning lips. The clinical findings are described in Table 2. In addition, Tables 3, 4 and 5 display AC incidence rates according to the epidemiological factors age, gender and occupational sun exposure, respectively.

Regarding the initial, clinical management of patients, conservative treatments were indicated for 78 patients, of which $46(58.9 \%)$ only used lip sunscreen was indicated, while 32 (41.1\%) used topical corticosteroids associated with lip sunscreen. Biopsies were performed in 83 patients and after microscopic examination and gradation of the specimens, 50 cases (60.2\%) were low-risk, while 33 (39.8\%) were high-risk, as defined in accordance with the criteria proposed by Kujan (2006).

Most of the high-risk ACs presented in men 
TABLE 1. Sample description according to gender, age, ethnicity, occupational sunlight exposure, clinical appearance and histological grading of the biopsied actinic cheilitis. Natal, Brazil, 2014.

\begin{tabular}{|c|c|c|}
\hline & $\mathbf{n}$ & $\%$ \\
\hline \multicolumn{3}{|l|}{ Gender } \\
\hline Male & 128 & 79.5 \\
\hline Female & 33 & 20.5 \\
\hline Total & 161 & 100 \\
\hline \multicolumn{3}{|l|}{ Age } \\
\hline$\geq 40$ years & 125 & 77.5 \\
\hline$<40$ years & 36 & 22.5 \\
\hline Total & 161 & 100 \\
\hline \multicolumn{3}{|l|}{ Ethnicity } \\
\hline White & 120 & 85.7 \\
\hline Mixed race & 19 & 13.6 \\
\hline Black & 01 & 0.7 \\
\hline Total $^{\text {a }}$ & 140 & 100 \\
\hline \multicolumn{3}{|c|}{ Occupational solar exposure } \\
\hline Yes & 118 & 80.3 \\
\hline No & 29 & 19.7 \\
\hline Total $^{\mathrm{a}}$ & 147 & 100 \\
\hline \multicolumn{3}{|l|}{ Smoker } \\
\hline Yes & 42 & 29.3 \\
\hline No & 101 & 70.7 \\
\hline Total $^{\mathrm{a}}$ & 143 & 100 \\
\hline \multicolumn{3}{|c|}{ Alcohol consumption } \\
\hline Yes & 21 & 14.7 \\
\hline No & 122 & 85.3 \\
\hline Total $^{\mathrm{a}}$ & 143 & 100 \\
\hline \multicolumn{3}{|c|}{ Histopathological Grade } \\
\hline High-Risk & 33 & 39.8 \\
\hline Low-Risk & 50 & 60.2 \\
\hline Total $^{\mathrm{b}}$ & 83 & 100 \\
\hline
\end{tabular}

SOURCE: Postgraduate Program in Oral Pathology - UFRN.

(a) Missing data; (b) Data refers only to biopsied cases.

$(84.8 \%)$ who were aged under $40(72.7 \%)$, white (90.2\%), with occupational sunlight exposure (62.5\%), nonsmokers (74.1\%), nondrinkers $(96.5 \%)$, with clinical appearance of white lesions (52.3\%) (Table 6). There was no statistically significant association between histological grading and demographical or clinical variables $(p>0.05)$.

\section{DISASSION}

$\mathrm{AC}$ is a potentially malignant condition of the lip and chronic solar irradiation is widely accepted as its main etiological factor. ${ }^{2}$ The malignant transformation rate of $\mathrm{AC}$ into squamous cell carcinoma (SCC) of
TABLE 2. Distribution of clinical findings in 161 cases of actinic cheilitis. Natal, Brazil, 2014.

\begin{tabular}{lll}
\hline Signs and Symptoms & $\mathbf{n}$ & $\mathbf{\%}$ \\
White plaques & 48 & 33.6 \\
Red and white plaques & 38 & 26.6 \\
Red plaques & 37 & 25.9 \\
Pigmented areas & 9 & 5.6 \\
Ulceration & 9 & 5.6 \\
Pain & 23 & 28.4 \\
Stinging/burning lips & 20 & 24.7 \\
\hline SOURCE: Postgraduate Program in Oral Pathology - UFRN.
\end{tabular}

the lip ranges from $10 \%$ to $30 \% .^{11}$ The results of this study showed the clinicopathological and clinical management of $161 \mathrm{AC}$ cases.

In the present study, $\mathrm{AC}$ was more frequent in men aged 40 years or above, in agreement with other studies. ${ }^{4,5}$ The predilection for middle-aged individuals is probably attributable to the fact that damage from solar radiation is cumulative over a lifetime. ${ }^{8,12} \mathrm{Low}$ $\mathrm{AC}$ rates in women can be explained by the use of more clothing or lipstick that act as protective factors, while the predilection for men may reflect more prolonged occupational sun exposure and later retirement compared with women. ${ }^{13,14}$ This was clearly borne out in our sample, as most men (85.6\%) reported to be exposure to sunlight due to their occupations.

Most ACs in the sample occurred in white individuals, confirming this already well-established predilection, as per other studies. ${ }^{1,5,11,13,14}$ Darker skin signifies a higher melanin concentration in the lip epithelium, and consequently, higher protectionagainst the carcinogenic action of UV radiation. ${ }^{15}$ Nevertheless, 20 individuals from the sample were dark brown- or black-skinned, demonstrating that $\mathrm{AC}$ is not exclusive to individuals of lighter complexion. Unexpectedly high AC incidence rates in some darker-skinned individuals may occur, though this is almost always related to chronic, occupational or recreational sun exposure. ${ }^{16}$

Occupational solar exposure is an important risk factor for $\mathrm{AC}$, especially in men. ${ }^{17}$ The prevalence of $\mathrm{AC}$ in studies that do not break down occupational activities is $0.2-0.45 \%^{18,19}$, while in studies involving only outdoor workers, rates vary from $15.5 \%$ to $39.6 \% .{ }^{1,20}$ Among individuals from the present sample, the majority $(80.3 \%)$ had undertaken occupational activities entailing chronic sun exposure, similarly to results from other studies. ${ }^{5,14,21}$ 
Table 3: Clinical and demographic information from the cases studied according to age. Natal, Brazil, 2014.

\begin{tabular}{|c|c|c|c|c|}
\hline Variable & & Age & & \\
\hline & & $\begin{array}{l}\geq 40 \text { years } \\
\mathrm{n}(\%)\end{array}$ & $\begin{array}{l}<40 \text { years } \\
\text { n }(\%)\end{array}$ & $\begin{array}{l}\text { TOTAL } \\
\text { n (\%) }\end{array}$ \\
\hline \multirow[t]{4}{*}{ Gender } & Male & $97(75.8)$ & $31(24.2)$ & $128(100)$ \\
\hline & Female & $28(84.8)$ & $5(15.2)$ & $33(100)$ \\
\hline & Total & 125 (77.6) & $36(22.4)$ & $161(100)$ \\
\hline & White & $94(78.3)$ & $26(21.7)$ & $120(100)$ \\
\hline \multirow{2}{*}{ Ethinicity } & Mixed race/Black & $14(70.0)$ & $06(30.0)$ & $20(100)$ \\
\hline & Total $^{\mathrm{a}}$ & 108 (77.1) & $32(22.9)$ & $140(100)$ \\
\hline \multirow[t]{3}{*}{ Occupational sunlight exposure } & Yes & $97(82.2)$ & $21(17.8)$ & $118(100)$ \\
\hline & No & $19(65.5)$ & $10(34.5)$ & $29(100)$ \\
\hline & Total $^{\mathrm{a}}$ & $116(78.9)$ & $31(21.1)$ & $147(100)$ \\
\hline \multirow[t]{3}{*}{ Smoker } & Yes & $39(92.9)$ & $03(7.1)$ & $42(100)$ \\
\hline & No & $74(73.3)$ & $27(26.7)$ & $101(100)$ \\
\hline & Total $^{a}$ & $113(79.0)$ & $30(21.0)$ & $143(100)$ \\
\hline \multirow[t]{3}{*}{ Drinker } & Yes & $18(85.7)$ & $03(14.3)$ & $21(100)$ \\
\hline & No & $94(77.0)$ & $28(23.0)$ & $122(100)$ \\
\hline & Total $^{\mathrm{a}}$ & $112(78.3)$ & $31(21.7)$ & $143(100)$ \\
\hline \multirow[t]{3}{*}{ Clinical Appearence } & White lesion & 37 (78.7) & $10(23.1)$ & $47(100)$ \\
\hline & Red / White and red lesion & $63(84.0)$ & $12(16.0)$ & $75(100)$ \\
\hline & Total $^{\mathrm{b}}$ & $100(82.0)$ & $22(18.0)$ & $122(100)$ \\
\hline
\end{tabular}

SOURCE: Postgraduate Program in Oral Pathology - UFRN.

(a) Missing data; (b) Some cases did not show the clinical aspects categorized.

The etiological potential of imbibing alcohol and smoking tobacco for AC is controversial. Nonetheless, lips are directly exposed to the carcinogens of tobacco, which may therefore contribute to the pathogenesis of AC and lip SCC. ${ }^{5,18,22}$ Markopoulos, AlbanidouFarmaki and Kayavis demonstrated the combination of smoking and working outdoors with occurrence of AC. ${ }^{5}$ They suggested that cigarette smoking might have a role in the preferential occurrence of $A C$ on the right side of the lower lip, due to smokers holding cigarettes mostly on the right side of the lip, as people are right-handed. In our cases, the vast majority of individuals were nonsmokers and nondrinkers, regardless of age group or gender.

Almost all ACs in the present sample affected the lower lip. In fact, AC rarely affects the upper lip, probably because of the chronic, direct, incident sunlight upon the lower, rather than upper, lip. ${ }^{4,16}$ Clinically, AC comprises a broad spectrum of presentation, including scaly or dry areas, atrophy in the lip vermilion, blurred demarcation between the lip vermilion border and the skin, and red or white plaques and ulceration. ${ }^{4,8,12,23}$ The presence of chronic ulcerations or erosions, nodularity and bleeding suggests progression to lip SCC. ${ }^{5,23}$ In our research, most ACs presented as a white plaque, as observed in the study by Sarmento et al. ${ }^{14}$ However, other studies have shown a predominance of red plaques and/or red and white plaques. ${ }^{3,4,5} \mathrm{AC}$ is usually asymptomatic, though patients sometimes complain about dryness, stinging/burning, persistent scaling and impaired lip mobility. ${ }^{3,4}$ Accordingly, in this study, a small but significant portion of patients reported stinging/ burning or pain in the lower lip.

Therapeutic approaches to AC seek to control the lesion clinically. Various therapeutic methods have been used in the management of AC and these can be non-surgical or surgical. ${ }^{8}$ When the injury is less 
TABLE 4. Clinical and demographic information from the cases studied according to gender. Natal, Brazil, 2014.

\begin{tabular}{|c|c|c|c|c|}
\hline \multirow[b]{2}{*}{ Variable } & & \multicolumn{3}{|l|}{ Gender } \\
\hline & & $\begin{array}{l}\text { Male } \\
\text { n (\%) }\end{array}$ & $\begin{array}{l}\text { Female } \\
\text { n (\%) }\end{array}$ & $\begin{array}{l}\text { TOTAL } \\
\text { n (\%) }\end{array}$ \\
\hline \multirow[t]{4}{*}{ Age } & $\geq 40$ years & 97 (77.6) & $28(22.4)$ & $125(100)$ \\
\hline & $<40$ years & $31(86.1)$ & $5(13.9)$ & $36(100)$ \\
\hline & Total & $128(79.5)$ & $33(20.5)$ & $161(100)$ \\
\hline & White & $99(82.5)$ & $21(17.5)$ & $120(100)$ \\
\hline \multirow[t]{2}{*}{ Ethinicity } & Mixed race/Black & $15(80.0)$ & $05(20.0)$ & $20(100)$ \\
\hline & Total $^{a}$ & $114(81.4)$ & $26(18.8)$ & $140(100)$ \\
\hline \multirow[t]{4}{*}{ Occupational sunlight exposure } & Yes & & & \\
\hline & No & $101(85.6)$ & $19(65.5)$ & 17 (14.4) \\
\hline & & $10(34.5)$ & $118(100)$ & $29(100)$ \\
\hline & Total $^{\mathrm{a}}$ & $120(81.6)$ & $27(18.4)$ & $147(100)$ \\
\hline \multirow[t]{3}{*}{ Smoker } & Yes & $35(83.3)$ & 07 (16.7) & $42(100)$ \\
\hline & No & 78 (77.2) & $23(22.8)$ & $101(100)$ \\
\hline & Total $^{\mathrm{a}}$ & $113(79.0)$ & $30(21.0)$ & $143(100)$ \\
\hline \multirow[t]{3}{*}{ Drinker } & Yes & $18(85.7)$ & $03(14.3)$ & $21(100)$ \\
\hline & No & $95(77.9)$ & $27(22.1)$ & $122(100)$ \\
\hline & Total $^{\mathrm{a}}$ & $113(79.0)$ & $30(21.0)$ & $143(100)$ \\
\hline \multirow[t]{3}{*}{ Clinical Appearence } & White lesion & $38(80.9)$ & $9(19.1)$ & 47 (100) \\
\hline & Red / White and red lesion & $60(80.0)$ & $15(20.0)$ & 75 (100) \\
\hline & Total $^{\mathrm{b}}$ & $98(80.3)$ & $24(19.7)$ & $122(100)$ \\
\hline
\end{tabular}

SOURCE: Postgraduate Program in Oral Pathology - UFRN.

(a) Missing data; (b) Some cases did not show the clinical aspects categorized.

aggressive, conservative treatment is more suitable, especially the use of lip sunscreen. In the present sample, conservative treatment, which included use of lip sunscreen and/or topical corticosteroids, was adopted in 78 cases. Solar protection needs to be associated with continuous, long-term monitoring, while in cases of changes in clinical appearance, such as the onset of ulcerations and nodularity, an incisional biopsy should be performed. According to Van der Waal $^{7}$, biopsies are indicated according to the clinical aspects of the disease, with the aim of monitoring patients for possible malignant transformation of lesions. It should be performed after failure of conservative treatment or if there is clinical suspicion of malignancy.

Biopsies enable clinicians to determine the degree of epithelial dysplasia in AC, serving as a basis to select the most adequate treatment for patients, remembering that high-grade dysplastic epithelium is more likely to undergo malignant transformation. ${ }^{4,10}$ The specimens in our research were graded using the binary system proposed by Kujan et al. ${ }^{10}$, complemented by the WHO criteria. ${ }^{24}$ In this system, oral epithelial dysplasia is classified as being of low-risk or high-risk malignant transformation. The smaller number of categories used by this system is thought to reduce the subjectivity inherent to other systems with intermediate categories. ${ }^{25}$

In our study, most ACs were graded as low-risk, similarly to the studies of Sarmento et al., ${ }^{14}$ Kaugars et al. $^{18}$ and Freitas et al. ${ }^{21}$ which all demonstrated a predominance of $\mathrm{AC}$ with mild, epithelial alterations. In contrast, ACs presenting graver epithelial dysplasia were more common in the samples studied by Cavalcante, Anbinder and Carvalho ${ }^{4}$ and Souza et al.. ${ }^{26}$ According to Sarmento et al. ${ }^{14}$, these differences may merely reflect the variations in time taken to diagnose lesions. Nevertheless, assessing the risk of 
TABLE 5: Clinical and demographic information from the cases studied according to occupational sunlight exposure. Natal, Brazil, 2014.

\begin{tabular}{|c|c|c|c|c|}
\hline \multirow[b]{2}{*}{ Variable } & & \multicolumn{3}{|c|}{ Occupational sunlight exposure ${ }^{\dagger}$} \\
\hline & & $\begin{array}{l}\text { Yes } \\
\text { n (\%) }\end{array}$ & $\begin{array}{l}\text { No } \\
\text { n (\%) }\end{array}$ & $\begin{array}{l}\text { TOTAL } \\
\text { n (\%) }\end{array}$ \\
\hline \multirow[t]{3}{*}{ Age } & $\geq 40$ years & $97(83.6)$ & $19(16.4)$ & $116(100)$ \\
\hline & $<40$ years & $21(63.0)$ & $10(37.0)$ & $31(100)$ \\
\hline & Total & $118(80.3)$ & 29 (19.7) & $147(100)$ \\
\hline \multirow[t]{4}{*}{ Gender } & Male & $101(84.2)$ & 19 (15.8) & $120(100)$ \\
\hline & Female & $17(63.0)$ & $10(37.0)$ & 27 (100) \\
\hline & Total & $118(80.3)$ & 29 (19.7) & $161(100)$ \\
\hline & White & $93(80.2)$ & $23(19.8)$ & $116(100)$ \\
\hline \multirow[t]{2}{*}{ Ethinicity } & Mixed race/Black & $15(79.0)$ & $04(21.0)$ & $19(100)$ \\
\hline & Total $^{\mathrm{a}}$ & $108(80.0)$ & $27(20.0)$ & $135(100)$ \\
\hline \multirow[t]{3}{*}{ Smoker } & Yes & $35(85.3)$ & 06 (14.7) & $41(100)$ \\
\hline & No & 75 (78.1) & 21 (21.9) & $96(100)$ \\
\hline & Total $^{\text {a }}$ & $110(80.3)$ & 27 (19.7) & $137(100)$ \\
\hline \multirow[t]{3}{*}{ Drinker } & Yes & $20(95.2)$ & $01(4.8)$ & $21(100)$ \\
\hline & No & 90 (77.6) & $26(22.4)$ & $116(100)$ \\
\hline & Total $^{\text {a }}$ & $110(80.3)$ & $27(19.7)$ & $137(100)$ \\
\hline \multirow[t]{3}{*}{ Clinical Appearence } & White lesion & $32(72.7)$ & $12(27.3)$ & $44(100)$ \\
\hline & Red/White and red lesion & $65(89.0)$ & $08(11.0)$ & $73(100)$ \\
\hline & Total $^{\mathrm{b}}$ & $97(82.9)$ & $20(17.1)$ & $117(100)$ \\
\hline
\end{tabular}

SOURCE: Postgraduate Program in Oral Pathology - UFRN.

(†) This information was available only in 147 cases; (a) Missing data; (b) Some cases did not show the clinical aspects categorized.

malignant transformation through histopathological grading may help to plan the next step of treatment. The plan for low-risk AC involves continuous solar protection, such as lip sunscreen, wide-brimmed hats and instructions to avoid sun exposure to the highest incidence of UV radiation time. Special care and rigorous monitoring are advisable for patients whose sun exposure is continuous due to their occupation. ${ }^{79}$ However, in cases with severe microscopic changes or clear malignant transformation, surgical excision (vermilionectomy), cryosurgery and laser surgery can be performed. ${ }^{9}$

There were no associations between histological grading of AC and demographical or clinical variables in the present sample, in accordance with the literature..$^{4,11,16,23}$ Generally, clinical presentation does not correlate with the degree of histologic abnormality in AC. ${ }^{16}$ This may be because AC often presents as multifocal lesions, both clinically and microscopically. Thus, in some situations, the fragment sent for histopathological examination may not be representative of the lesion's actual degree of morphological severity. ${ }^{4,11,12,14}$ However, it is important to note that most high-risk ACs were found in men aged over 40 with white skin, whose occupational activities entailed sun exposure. This reinforces the hypothesis that early identification of individuals at risk is essential to establish interceptive treatment, preventing malignant transformation.

Despite being a preventable disease with easy clinical diagnosis, several factors can be attributed to late clinical diagnosis of AC: patient's unawareness of the entity, absence of pain, initially harmless clinical appearance and lack of knowledge from many 
TABLE 6: Absolute and relative distribution of cases in terms of gender, age and clinical aspect according to histological grading of actinic cheilitis. Natal, Brazil, 2014.

\begin{tabular}{|c|c|c|c|c|c|}
\hline \multirow[t]{2}{*}{ Variable } & & \multicolumn{4}{|c|}{ Histopathological Grading } \\
\hline & & $\begin{array}{l}\text { High-Risk } \\
\text { n (\%) }\end{array}$ & $\begin{array}{l}\text { Low-Risk } \\
\text { n (\%) }\end{array}$ & $\begin{array}{l}\text { TOTAL } \\
\text { n (\%) }\end{array}$ & p \\
\hline \multirow[t]{3}{*}{ Gender } & Male & $28(38.4)$ & $45(61.6)$ & $73(100)$ & $0.509^{*}$ \\
\hline & Female & $05(50.0)$ & $05(50.0)$ & $10(100)$ & \\
\hline & Total & $33(39.8)$ & $50(60.2)$ & $83(100)$ & \\
\hline \multirow[t]{4}{*}{ Age } & $\geq 40$ years & $09(50.0)$ & $09(50.0)$ & $18(100)$ & $0.416^{* *}$ \\
\hline & $<40$ years & $24(36.9)$ & $41(68.1)$ & $65(100)$ & \\
\hline & Total & $33(39.8)$ & $50(60.2)$ & $83(100)$ & \\
\hline & White & $29(43.9)$ & $37(56,1)$ & $66(100)$ & $0.388^{*}$ \\
\hline \multirow[t]{2}{*}{ Ethinicity } & Mixed race/Black & $01(20.0)$ & $04(80,0)$ & $05(100)$ & \\
\hline & Total $^{\text {a }}$ & $30(42,3)$ & $41(57.7)$ & $71(100)$ & \\
\hline \multicolumn{6}{|c|}{ Occupational sunlight exposure } \\
\hline & Yes & $40(62.5)$ & $08(61.5)$ & $24(37.5)$ & \\
\hline & No & $05(38.5)$ & $64(100)$ & $13(100)$ & $1.000^{*}$ \\
\hline & Total $^{\mathrm{a}}$ & $48(62.3)$ & $29(37.7)$ & $77(100)$ & \\
\hline \multirow[t]{3}{*}{ Smoker } & Yes & $08(57.1)$ & $06(42.9)$ & $14(100)$ & $0.230^{* *}$ \\
\hline & No & $23(37.1)$ & $39(62.9)$ & $62(100)$ & \\
\hline & Total $^{a}$ & $31(40.8)$ & $45(59.2)$ & $76(100)$ & \\
\hline \multirow[t]{3}{*}{ Drinker } & Yes & $01(25.0)$ & $03(75.0)$ & $04(100)$ & $1.000^{*}$ \\
\hline & No & $28(40.0)$ & $42(60,0)$ & $70(100)$ & \\
\hline & Total $^{a}$ & $29(39.2)$ & $45(60.8)$ & $74(100)$ & \\
\hline \multirow[t]{3}{*}{ Clinical Appearence } & White lesion & $22(62.7)$ & $12(35.8)$ & $34(100)$ & $0.803^{* *}$ \\
\hline & Red / White and red lesion & $20(58.8)$ & $14(41.2)$ & $34(100)$ & \\
\hline & Total $^{\text {b }}$ & $42(61.8)$ & $26(38.2)$ & $68(100)$ & \\
\hline
\end{tabular}

SOURCE: Postgraduate Program in Oral Pathology - UFRN.

$\left.{ }^{*}\right)$ Fisher's exact test; $\left.{ }^{(*}\right)$ Pearson's chi-squared test; (a) Missing data; (b) Some cases did not show the clinical aspects categorized.

professionals who may consider it a simple, chronic, inflammatory process. Due to slow progression, patients overlook the lesion or attribute it to aging until it evolves into advanced stages or SCC of the lip. ${ }^{4}$ This was evident in our study, since in our initial sample, 5 patients who were clinically diagnosed with AC received the histopathological diagnosis of SCC of the lower lip.

\section{CONQLUSION}

The data presented in this study corroborate the profile of individuals with AC frequently reported in the literature: white males, aged over 40, who work outdoors, need careful examination of the lips, daily sun protection and long-term monitoring. Additionally, the clinical and demographic features showed no association with the histopathological risk of malignization of lesions, suggesting that biopsy results are determinant in choosing the most appropriate and individualized course of therapeutic management. 


\section{REFERENCES}

1. de Souza Lucena EE, Costa DC, da Silveira EJ, Lima KC. Prevalence and factors associated to ACin beach workers. Oral Dis. 2012;18:575-9.

2. Wood NH, Khammissa R, Meyerov R, Lemmer J, Feller L. Actinic Cheilitis: A Case Report and a Review of the Literature. Eur J Dent. 2011;5:101-6.

3. Miranda OMA, Ferrari MT, Calandro LLT. Queilite Actínica: Aspectos Clínicos e Prevalência Encontrados em uma População Rural do Interior do Brasil. Saud Pesq. 2011;4:67-72.

4. Cavalcante AS, Anbinder AL, Carvalho YR. Actinic cheilitis: clinical and histological features. J Oral Maxillofac Surg. 2008;66:498-503

5. Markopoulos A, Albanidou-Farmaki E, Kayavis I. Actinic cheilitis: clinical and pathologic characteristics in 65 cases. Oral Dis. 2004;10:212-6.

6. Bertini F, Sgarbi FC, Tera TM, Brandão AAH, Cavalcante ASR. Histological analysis of the actinic cheilitis: an interobserver approach. Int J Dent. 2010;9:6-10.

7. van der Waal I. Potentially malignant disorders of the oral and oropharyngeal mucosa; terminology, classification and present concepts of management. Oral Oncol. 2009;45:317-23.

8. Savage NW, McKay C, Faulkner C. Actinic Cheilits in dental pratice. Aust Dent J. 2010;55:78-84.

9. Shah AY, Doherty SD, Rosen T. Actinic cheilitis: a treatment review. Int J Dermatol. 2010;49:1225-34

10. Kujan 0, Oliver RJ, Khattab A, Roberts SA, Thakker N, Sloan P. Evaluation of a new binary system of grading oral epithelial dysplasia for prediction of malignant transformation. Oral Oncol. 2006;42:987-93.

11. Piñera-Marques K, Lorenço SV, Silva LF, Sotto MN, Carneiro PC. Actinic lesions in fishermens lower lip: clinical, cytopathological and histopathologic analysis. Clinics (Sao Paulo). 2010;65:363-7

12. Vieira RA, Minicucci EM, Marques ME, Marques SA. ACand squamous cell carcinoma of the lip: clinical, histopathological and imumunogenetic aspects. An Bras Dermatol. 2012;87:105-14.

13. Martins-Filho PR, Da Silva LC, Piva MR. The prevalence of ACin farmers in a semiarid northeastern region of Brazil. Int J Dermatol. 2011;50:1109-14.

14. de Santana Sarmento DJ, da Costa Miguel MC, Queiroz LM, Godoy GP, da Silveira EJ. Actinic cheilitis: clinicopathologic profile and association with degree of dysplasia. Int J Dermatol. 2014;53:466-72.

15. Thibodeau EA, D'Ambrosio JA. Measurement of lip and skin pigmentation using reflectance spectrophotometry. Eur J Oral Sci. 1997;105:373-5.

16. Jadotte YT, Schwartz RA. Solar cheilosis: an ominous precursor: part I. Diagnostic insights. J Am Acad Dermatol. 2012;66:173-84.

17. Pukkala E, Martinsen Jl, Lynge E, Gunnarsdottir HK, Sparén P, Tryggvadottir L, et al. Occupation and cancer - follow-up of 15 million people in five Nordic countries. Acta Oncol. 2009;48:646-790.
18. Kaugars GE, Pillion T, Svirsky JA, Page DG, Burns JC, Abbey LM. Actinic cheilitis: a review of 152 cases. Oral Surg Oral Med Oral Pathol Oral Radiol Endod. 1999:88:181-6.

19. Corso FM, Wild C, Gouveia LO, Ribas MO. Actinic cheilitis: prevalence in dental clinics from PUCPR, Curitiba, Brazil. Clin Pesq Odontol. 2006;2: 277-81.

20. Junqueira JL, Bönecker M, Furuse C, Morais Pde C, Flório FM, Cury PR, et al. ACamong agricultural workers in Campinas, Brazil. Community Dent Health. 2011;28:60-3.

21. de Freitas Mda C, Ramalho LM, Xavier FC, Moreira AL, Reis SR. p53 and MDM2 protein expression in actinic cheilitis. J Appl Oral Sci. 2008;16:414-9.

22. Jovanovic A, Schulten EA, Kostense PJ, Snow GB, van der Waal I. Squamous cell carcinoma of the lip and oral cavity in The Netherlands; an epidemiological study of 740 patients. J Craniomaxillofac Surg. 1993;21:149-52.

23. Menta Simonsen Nico M1, Rivitti EA, Lourenço SV. Actinic cheilitis: histologic study of the entire vermilion and comparison with previous biopsy. J Cutan Pathol. 2007;34:309-14.

24. Barnes L, Eveson JW, Reichart P, Sindransky D. World Health Organization classification of tumours. Pathology and genetics of head and neck tumours. Lyon: IARC Press; 2005.

25. Warnakulasuriya S. Global epidemiology of oral and oropharyngeal cancer. Oral Oncol. 2009;45:309-16.

26. Souza LR, Fonseca-Silva T, Pereira CS, Santos EP, Lima LC, Carvalho HA, et al. Immunohistochemical analysis of p53, APE1, hMSH2 and ERCC1 proteins in ACand lip squamous cell carcinoma. Histopathology. 2011;58:352-60.

M AILING ADDRESS:

M aria Luiza D iniz de Sousa Lopes

A v Senador Sal gado Filho, 1787

Lagoa N ova

59056-000 N atal, RN .

E-mail: marialu.diniz@gmail.com

How to cite this artide: Lopes MLDS, Silva Júnior FL, Lima KC, Oliveira PT, Silveira EJD. Clinicopathological profile and management of 161 cases of actinic cheilitis. An Bras Dermatol. 2015;90(4):505-12. 